\title{
INACTIVATION OF ENDOTOXIN BY A HUMORAL COMPONENT. VII. ENZYMATIC DEGRADATION OF ENDOTOXIN BY BLOOD PLASMA *
}

\author{
By WILLIS R. KEENE, $\dagger$ MAURICE LANDY AND MURRAY J. SHEAR with THE \\ ASSISTANCE OF KATHERINE A. STRELECKY
}

(From the Laboratory of Chemical Pharmacology, National Cancer Institute, Bethesda, Md.)

(Submitted for publication July 27, 1960; accepted September 30, 1960)

The pathogenesis of the febrile response that follows the intravenous injection of bacterial endotoxin has been the subject of extensive investigations. In the course of these studies it became evident that blood serum contains factors which, when interacted in vitro with endotoxin, may either enhance or inactivate the fever-producing effects. LeQuire demonstrated that a brief period of interaction between serum and endotoxin results in augmentation of pyrogenicity (3). Others have confirmed this observation and have, in addition, defined some of the conditions necessary for demonstrating the pyrogen-enhancing effect of serum (4-8).

In seeking to explain the termination of endotoxin fever, Hegemann postulated that this was effected by components of serum capable of detoxifying endotoxin. $\mathrm{He}$ demonstrated the presence of such agents in serum by incubating endotoxin and serum for prolonged periods at physiological temperature (9-12). However, these experiments did not provide evidence that this effect of serum was operative in the termination of endotoxin fever.

The observations of LeQuire and of Hegemann were confirmed by Cluff and Bennett (8), who clearly distinguished the two effects of serum by demonstrating that pyrogen augmentation was not dependent upon the time or temperature of incuba-

* In previous reports it was convenient to use a brief, tentative designation (EDC) for the component in blood responsible for the detoxification of endotoxin in vitro. More recent studies in this Laboratory indicate that there may be more than one host enzyme capable of catalyzing this reaction; e.g., endotoxin can be inactivated in vitro by tissue homogenates under conditions which differ from those required for detoxification by blood $(1,2)$. In the present report, the host product employed as a source of endotoxin-inactivating enzyme is referred to, simply, as plasma or serum.

$\dagger$ Present address: U. S. Public Health Service Hospital, Boston, Mass. tion and that this effect of serum was due to a relatively heat-stable factor. Inactivation of pyrogen, on the other hand, was dependent upon a heat-labile factor and was evident only after prolonged incubation at physiological temperature (8).

Other investigators working on different facets of the problem have made it evident that reaction of serum and endotoxin under appropriate conditions results in the inactivation of every hostreactive property of endotoxin thus far examined $(13-20)$ as well as in striking alterations in the immunochemical properties of the lipopolysaccharide complex $(7,19)$.

However, the mechanism by which endotoxin is inactivated by plasma has remained uncertain. Studies reported here show that inactivation of endotoxin by plasma in vitro has the characteristics of an enzyme-catalyzed reaction.

\section{MATERIALS AND METHODS}

The experiments were carried out with endotoxin derived from Serratia marcescens (lot P-45). The chemical composition and physical properties of this preparation were summarized in the preceding paper (21). Pyrogen assays were carried out in rabbits under experimental conditions that conformed to the specifications described previously. All injections were made intravenously. The methods used in computing the fever index, recording of temperatures, and avoiding pyrogen contamination of glassware, needles, and syringes are described in the preceding report (21).

Plasma. Because calcium was found to inhibit partially the inactivation of endotoxin by serum (22), either citrated or resin-treated (Fenwal ion-exchange pack no. JB-2) plasma was used. Human blood was collected through an ion-exchange resin to prevent clotting. Blood from experimental animals was collected under aseptic conditions in sodium citrate $(0.02 \mathrm{M})$; plasma from three or more animals was pooled in each instance, and was stored at $-20^{\circ} \mathrm{C}$. All samples were demonstrated to be nonpyrogenic in doses of $1 \mathrm{ml}$ per animal (the largest dose administered). 
Réation mitrlures. Endotoxin in 0.2 to $4.0 \mathrm{ml}$ of normal saline was added to the appropriate dilution of plasma. The concentrations of endotoxin and of plasma in the reaction mixtures were expressed as micrograms per milliliter and per $100 \mathrm{ml}$, respectively. The $\mathrm{pH}$ was adjusted by the addition of concentrated hydrochloric acid or sodium hydroxide. Pyrogen-free Ringer's phosphate buffer containing $0.132 \mathrm{M} \mathrm{NaCl}, 0.005 \mathrm{M} \mathrm{KCl}, 0.001 \mathrm{M}$ $\mathrm{KH}_{2} \mathrm{PO}_{4}$, and $0.01 \mathrm{M} \mathrm{NaH}_{2} \mathrm{PO}_{4}$ was used as diluent.

Conditions of reaction. As shown in the preceding paper, dose-related pyrogen assays yield the highest precision when performed in the linear portion of the dosefebrile response curve (21). Thus, in the studies reported here the conditions for each experiment were selected so that the febrile responses fell on that portion of the dose-response curve. The specific conditions employed in the reaction of plasma with endotoxin are described for each set of experiments.

Calculation of reaction rate. The degradation of endotoxin by plasma was followed by measuring the pyrogenicity of an aliquot of the reaction mixture before and after incubation. The pyrogenic response to the unincubated aliquot served as a control for determining the amount of endotoxin degraded in a given time interval. In the assays, groups, of four animals each, were given equal aliquots of the unincubated or incubated reaction mixture. The mean fever index for each group provided a relative measure of endotoxin concentration. The rate of degradation was calculated according to the following equation: Rate $=(\mathrm{A}-\mathrm{B}) / \mathrm{T}$, where $\mathrm{A}$ represents the mean fever index following the injection of an aliquot of the unincubated mixture; $\mathrm{B}$, the mean fever index following the injection of an aliquot of incubated mixture; and $\mathrm{T}$, the duration of incubation in minutes. The rate of degradation is thus expressed as centimeters ${ }^{2}$ per minute.

Induction of endotoxin tolerance. On Days 1 and 2, animals were given $10 \mu \mathrm{g}$; on Day 3,20 $\mathrm{g}$; and on Days 4 through 8 , they received $50 \mu \mathrm{g}$ daily. Tolerance to a dose of $10 \mu \mathrm{g}$ was demonstrated on the ninth day, after which the animals were again given $50 \mu \mathrm{g}$ of endotoxin. Thus, on the day before the crucial experiment, which was carried out on the tenth day, the animals received a total of $60 \mu \mathrm{g}$ of endotoxin.

Tumor-bearing mice. $\mathrm{CAF}_{1}$ mice of both sexes weighing 19 to $22 \mathrm{~g}$ were obtained from the Animal Production Unit, National Institutes of Health. Sarcoma 37 was implanted into the thigh muscle, as previously described (23), and the induction of hemorrhagic necrosis by endotoxin was determined by necropsy 18 to 24 hours after the test injection which was given on the sixth day of tumor growth. The response was graded from 0 to $4+$ depending upon the extent of induced tumor necrosis. Only severe, unequivocal, hemorrhagic necrosis scored as $3+$ and $4+$ was considered a positive reaction.

Adrenalectomized mice. $\mathrm{CAF}_{1}$ male mice were adrenalectomized under ether anesthesia 24 hours before injection. Thereafter, the animals were maintained on normal saline and food ad lib. Lethality was recorded 48 hours after the test injection of endotoxin.

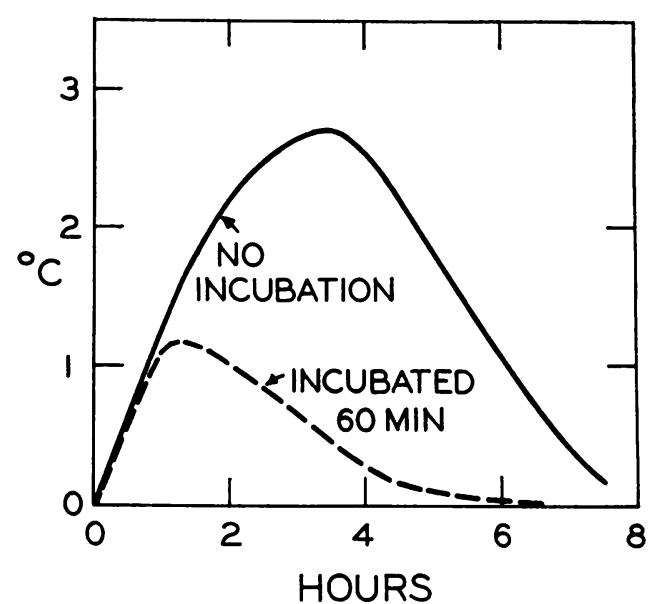

Fig. 1. The febrile response to equal aliquots of A PLASMA-ENDOTOXIN REACTION MIXTURE BEFORE AND After incubation. Conditions of reaction: resin-treated human plasma 80 per cent, concentration of endotoxin $200 \mu \mathrm{g}$ per $\mathrm{ml}, \mathrm{pH} 7.4$, incubated 60 minutes at $37^{\circ} \mathrm{C}$. Aliquot testcd: $0.10 \mathrm{ml}$ per animal.

\section{EXPERIMENTAL}

As will be shown, many variables were capable of affecting the capacity of plasma to degrade endotoxin. However, under appropriate conditions large amounts of endotoxin were rapidly degraded. Figure 1 illustrates the mean febrile response of two groups of four animals each. One group was given an aliquot of unincubated endotoxin and plasma; the second group received an aliquot of the same reaction mixture after 1 hour of incubation at $37^{\circ} \mathrm{C}$. The mean fever indices were 78 and $20 \mathrm{~cm}^{2}$, respectively.

\section{Effect of plasma on the lethal, tumor-necrotizing, and pyrogenic properties of endotoxin}

The data in Table I, obtained with a single reaction mixture in three different kinds of bioassay, serve to emphasize that reduction of the pyrogenic potency of endotoxin was consistently accompanied by reduction of other toxic properties.

Other experiments showed that large doses of plasma-degraded endotoxin failed to produce leukopenia when injected into normal rabbits and were not lethal for animals with reticuloendothelial blockade.

\section{Heat lability}

Heating of plasma at $50^{\circ} \mathrm{C}$ resulted in a progressive diminution of enzymatic activity (Table 
TABLE: I

Inactivation by plasma of three biological properties of endotoxin*

\begin{tabular}{cccrc}
\hline \hline $\begin{array}{c}\text { Endo- } \\
\text { toxin }\end{array}$ & $\begin{array}{c}\text { Incuba- } \\
\text { tion }\end{array}$ & $\begin{array}{c}\text { Mean } \\
\text { fever } \\
\text { index }\end{array}$ & $\begin{array}{c}\text { Tumor } \\
\text { necrosis } \dagger\end{array}$ & Lethality $\ddagger$ \\
\hline$\mu g /$ animal & & $\mathrm{cm}^{2}$ & & \\
2 & - & 39 & $10 / 10$ & $9 / 10$ \\
& + & 11 & $1 / 10$ & $0 / 10$ \\
4 & - & 55 & $10 / 10$ & $10 / 10$ \\
& + & 11 & $2 / 10$ & $0 / 10$ \\
& & 78 & &. \\
& - & 25 & & \\
& + & & & \\
\end{tabular}

* Reaction conditions : resin-treated human plasma $80 \%$, endotoxin concentration $200 \mu \mathrm{g}$ per $\mathrm{ml}, \mathrm{pH} 7.2$, incubated $60 \mathrm{~min}$ at $37^{\circ} \mathrm{C}$

$\dagger$ No. of necrotic tumors per no. tested.

$\ddagger$ Adrenalectomized mice: no. dead per no."tested.

II). In these experiments the concentration of plasma in the reaction mixtures was limited to 36 per cent, so that small changes in enzymatic activity would be more readily discernible. However, when the plasma concentration was doubled it was evident that, under these conditions of heating, destruction of enzyme was only partial.

Factors which alter the rate of endotoxin degradation by plasma

A. Temperature of incubation. Below the physiological temperature, degradation of endotoxin by plasma proceeded slowly (Figure 2). The rate was doubled on increasing the temperature of incubation from $40^{\circ}$ to $50^{\circ} \mathrm{C}$. To be sure that substrate (endotoxin) and enzyme would remain in excess throughout the period of incubation, the reaction time was limited to 10 minutes for the

TABLE II

Heat lability*

\begin{tabular}{|c|c|c|}
\hline $\begin{array}{l}\text { Pretreatment of } \\
\text { plasma }\end{array}$ & $\begin{array}{l}\text { Incubation } \\
\text { at } 37^{\circ} \mathrm{C}\end{array}$ & $\begin{array}{c}\text { Mean } \\
\text { fever } \\
\text { index } \dagger\end{array}$ \\
\hline $\begin{array}{c}\text { None } \\
\text { None } \\
60 \mathrm{~min} \text { at } 37^{\circ} \mathrm{C} \\
15 \mathrm{~min} \text { at } 50^{\circ} \mathrm{C} \\
30 \mathrm{~min} \text { at } 50^{\circ} \mathrm{C} \\
60 \mathrm{~min} \text { at } 50^{\circ} \mathrm{C}\end{array}$ & $\begin{array}{c}\min \\
\text { None" } \\
60 \\
60 \\
60 \\
60 \\
60\end{array}$ & $\begin{array}{l}\mathrm{cm}^{2} \\
68 \\
44 \\
43 \\
47 \\
54 \\
72\end{array}$ \\
\hline
\end{tabular}

* Reaction conditions : resin-treated human plasma $36 \%$. endotoxin concentration $142 \mu \mathrm{g}$ per $\mathrm{ml}, \mathrm{pH} 7.1$, incubated $60 \mathrm{~min}$ at $37^{\circ} \mathrm{C}$

$\dagger$ Aliquot tested: $0.14 \mathrm{ml}$ per animal.

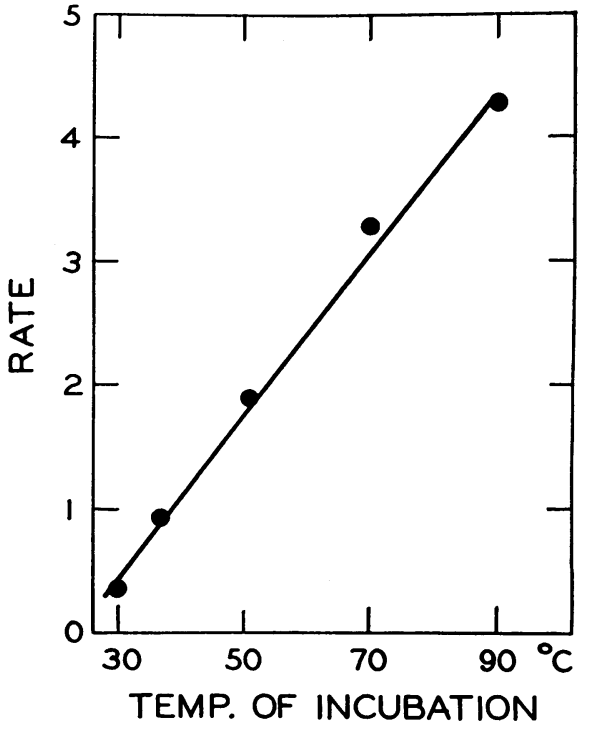

Fig. 2. The rate of endotoxin inactivation by plasma at various temperatures of Incubation. Conditions of reaction: resin-treated human plasma 72 per cent, concentration of endotoxin $142 \mu \mathrm{g}$ per $\mathrm{ml}, \mathrm{pH} 7.3$, incubated 10 to 30 minutes. Aliquot tested: $0.14 \mathrm{ml}$ per animal.

higher temperatures $\left(70^{\circ}\right.$ and $\left.90^{\circ} \mathrm{C}\right)$, and to 30 minutes for the lower temperatures. These findings indicate that at higher temperatures the degradation of endotoxin occurred more rapidly than heat destruction of the enzyme.

$B$. Concentration of endotoxin in the reaction mixture. The enzymatic nature of the reaction between plasma and endotoxin was fully appreciated only after it was observed that the degradation of endotoxin proceeded more rapidly in reaction mixtures containing high concentrations of endotoxin than in mixtures containing low concentrations. Experiments were then designed to study the influence of endotoxin concentration on the reaction velocity. Reaction mixtures containing endotoxin in concentrations ranging from 7.5 to $194 \mu \mathrm{g}$ per $\mathrm{ml}$ were incubated with an excess of plasma. The biological assay was not sufficiently sensitive to determine initial reaction velocity; accordingly, the assays were performed with a reaction time of 30 minutes. When the velocity of the reaction was plotted against concentration of endotoxin (Figure 3), a mixed order reaction curve was obtained. Below $80 \mu \mathrm{g}$ per $\mathrm{ml}$ the rate of endotoxin degradation was dependent upon the concentration of endotoxin. However, above 100 


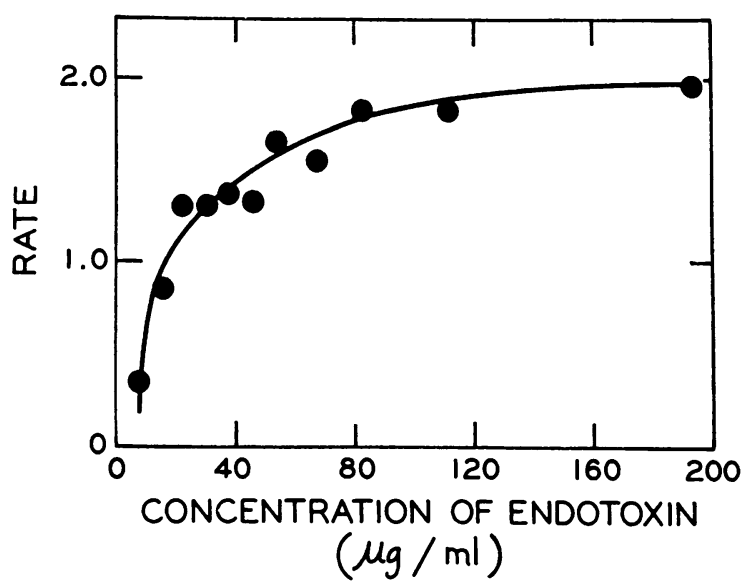

Fig. 3. The EFFECT OF CONCENTRATION OF ENDOTOXIN on the rate of inactivation by plasma. Conditions of reaction: citrated rabbit plasma 70 per cent, $\mathrm{pH} 7.6$, incubated 30 minutes at $37^{\circ} \mathrm{C}$. Aliquot tested: 0.10 to $2.67 \mathrm{ml}$ per animal.

$\mu \mathrm{g}$ per $\mathrm{ml}$ the rate was not significantly influenced by increased concentration. Under the specific conditions of this experiment, the MichaelisMenten constant was estimated to be $17 \mu \mathrm{g}$ per $\mathrm{ml}$.

$C$. Concentration of plasma in the reaction mixture. Reaction mixtures containing an excess of endotoxin (142 $\mu \mathrm{g}$ per $\mathrm{ml})$ and concentrations of plasma ranging from 18 to 72 per cent, demonstrated that the velocity of degradation is also dependent upon the concentration of plasma in the

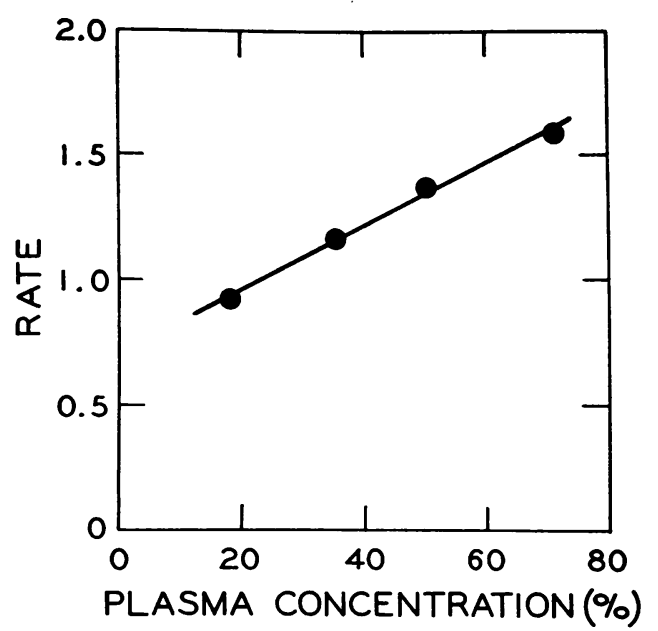

Fig. 4. EFFect of the CONCENTRATION OF PLASMa on rHE RATE OF ENDotoxin inactivation. Conditions of reaction: citrated rabbit plasma 18 to 72 per cent, concentration of endotoxin $142 \mu \mathrm{g}$ per $\mathrm{ml}, \mathrm{pH} \mathrm{7.6}$, incubated 30 minutes at $37^{\circ}$ C. Aliquot tested: $0.14 \mathrm{ml}$ per animal.

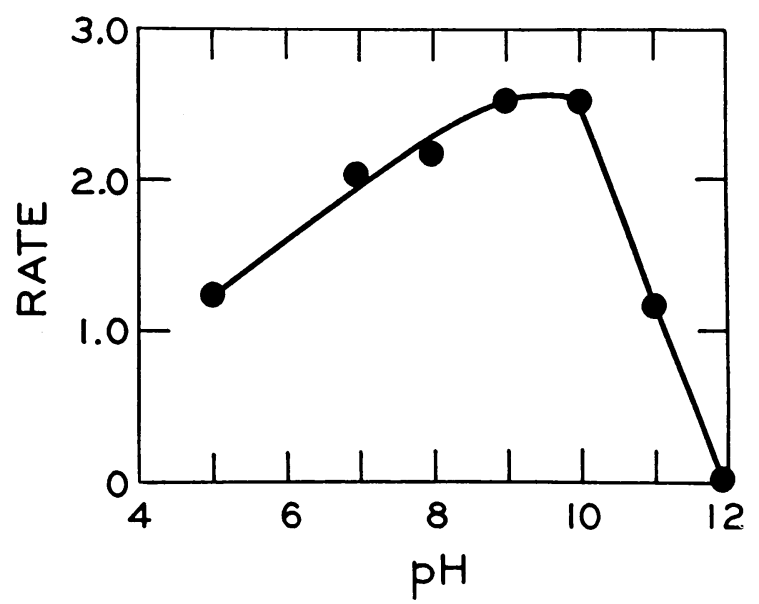

Fig. 5. The RATE OF ENDotoxin inactivation BY plasma in REACtion mixtures of Different pH. Conditions of reaction: citrated rabbit plasma 36 per cent, concentration of endotoxin $142 \mu \mathrm{g}$ per $\mathrm{ml}$, incubated for 15 minutes at $37^{\circ} \mathrm{C}$. Aliquot tested: $0.14 \mathrm{ml}$ per animal.

reaction mixture. Figure 4 shows the reaction rates for different plasma concentrations. The reaction time was limited to 30 minutes so that the concentration of substrate would remain in excess throughout the period of incubation. The linear relationship between reaction velocity and plasma concentration indicated that this was accomplished and that the reaction rate in this situation was altered only by variation in plasma concentration.

D. $p H$ of the reaction mixture. The degradation of endotoxin by plasma proceeded over a wide $\mathrm{pH}$ range, but the optimum was between 9 and 10 (Figure 5). In this experiment the reaction time was limited to 15 minutes so that the febrile responses to endotoxin, reacted with plasma at $\mathrm{pH}$ 9 to 10 , would fall in the linear portion of the dose-response curve. It was shown in control experiments that the $\mathrm{pH}$ of comparable reaction mixtures did not change significantly during this period of incubation.

\section{Pyrogenic properties of reaction products}

Early in the course of these studies the question arose as to whether the pyrogenic activity, remaining after prolonged incubation of endotoxin with plasma, is due to products of the reaction or to unaltered residual endotoxin. The data illustrated in Figure 6 were obtained by sampling a single reaction mixture periodically during 24 hours of incubation. At physiological temperature and $\mathrm{pH}$, 


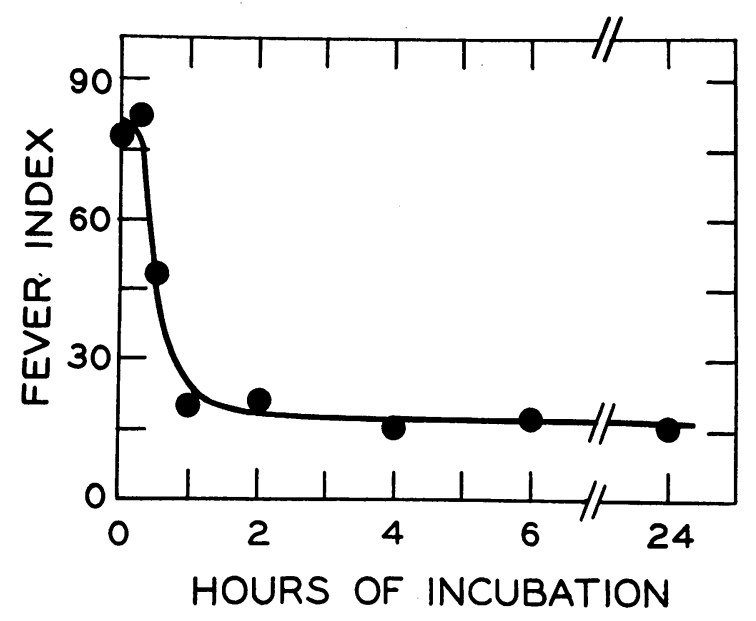

Fig. 6. The PROGRESSION OF ENDOTOXIN INACTIVATION BY PLASMA DURING PROLONGED INCUBATION. A single reaction mixture was periodically tested for pyrogenicity during 24 hours of incubation. Conditions of reaction: resin-treated human plasma 80 per cent, concentration of endotoxin $200 \mu \mathrm{g}$ per $\mathrm{ml}, \mathrm{pH} 7.4$, incubated 24 hours at $37^{\circ} \mathrm{C}$. Aliquot tested: $0.10 \mathrm{ml}$ per animal.

and after 1 to 2 hours of incubation, the febrile responses to aliquots of the reaction mixture remained constant.

There are several factors to be considered as possibly accounting for the apparent lack of further degradation of endotoxin after 1 to 2 hours of incubation. Gradual deterioration of the enzyme, because of its heat-lability, was ruled out since heating of plasma for 1 hour at $37^{\circ} \mathrm{C}$ did not alter the level of enzymatic activity (Table II). Inhibition by reaction products appears to be a relatively minor factor in view of the great excess of enzyme. The possibility that the reaction products are pyrogenic is considered in a later section. However, the concentration of residual endotoxin (substrate) in the reaction mixture may well be the limiting factor. After 2 hours of incubation the data indicate that approximately 99 per cent of the endotoxin originally present had been degraded, i.e., the concentration of endotoxin would be about $2 \mu \mathrm{g}$ per $\mathrm{ml}$.

Table III shows that rabbits made tolerant to endotoxin were also tolerant to the residual pyrogen in the incubated reaction mixture. Each of six normal rabbits was given $10 \mu \mathrm{g}$ aliquots of a reaction mixture which had been incubated for 1 hour. Subsequently, the same animals were made tolerant to endotoxin by daily injections of large
TABLE III

Residual pyrogenicity of plasma-endotoxin reaction mixtures in normal and tolerant animals *

\begin{tabular}{|c|c|c|c|c|c|c|c|}
\hline \multirow[b]{2}{*}{ Recipients } & \multicolumn{6}{|c|}{$\begin{array}{l}\text { Fever indices of individual } \\
\text { animals }\end{array}$} & \multirow{2}{*}{$\begin{array}{l}\text { Mean } \\
\text { fever } \\
\text { index } \dagger\end{array}$} \\
\hline & $\mathrm{A}$ & B & $\mathrm{C}$ & $\mathrm{D}$ & $\mathrm{E}$ & $\bar{F}$ & \\
\hline & & & & & & & $\mathrm{cm}^{2}$ \\
\hline $\begin{array}{l}\text { Normal } \\
\text { Tolerant }\end{array}$ & $\begin{array}{r}20 \\
1\end{array}$ & $\begin{array}{r}26 \\
3\end{array}$ & $\begin{array}{r}29 \\
2\end{array}$ & $\begin{array}{l}21 \\
10\end{array}$ & $\begin{array}{r}18 \\
4\end{array}$ & $\begin{array}{r}34 \\
7\end{array}$ & $\begin{array}{r}25 \\
4\end{array}$ \\
\hline
\end{tabular}

* Reaction conditions: citrated rabbit plasma $98 \%$ endotoxin concentration $10 \mu \mathrm{g}$ per $\mathrm{ml}, \mathrm{pH} 7.6$, incubated $60 \mathrm{~min}$ at $37^{\circ} \mathrm{C}$.

R $†$ Aliquot tested: $1 \mathrm{ml}$ per animal.

doses of endotoxin in physiological saline. After nine daily injections the animals were again challenged with $10 \mu \mathrm{g}$ aliquots of the plasma-endotoxin reaction mixture. These findings provide additional evidence that the residual pyrogen is undegraded endotoxin.

Experiments were next performed to obtain more direct information on the capacity of the reaction products to produce fever. Five separate reaction mixtures in which the endotoxin concentration was varied between 72 and $500 \mu \mathrm{g}$ per $\mathrm{ml}$ were incubated at $37^{\circ} \mathrm{C}$ for periods ranging from 2.5 to 5 hours; the $\mathrm{pH}$ was varied from 7.4 to 9.6 (Table IV). These various reaction mixtures were tested for pyrogenic activity in rabbits. Although the dose of degraded endotoxin per animal was varied 50 -fold, there was no significant difference in the mean fever index. Since the amount of reaction products also varied 50 -fold, these findings indicate that the residual pyrogenicity is due not to the reaction products, but rather to undegraded endotoxin.

TABLE IV

Pyrogenicity of reaction mixtures containing different quantities of degraded endotoxin *

\begin{tabular}{cc}
\hline $\begin{array}{c}\text { Dose per } \\
\text { animal } \dagger\end{array}$ & $\begin{array}{c}\text { Mean fever } \\
\text { indext }\end{array}$ \\
\hline$\mu g$ & $\mathrm{~cm}^{2}$ \\
10 & 23 \\
20 & 32 \\
40 & 28 \\
100 & 27 \\
500 & 29
\end{tabular}

* Reaction conditions : resin-treated human plasma $72 \%$, endotoxin concentration 72 to $500 \mu \mathrm{g}$ per $\mathrm{ml}, \mathrm{pH} 7.4$ to 9.6 , incubated 2.5 to $5 \mathrm{hrs}$ at $37^{\circ} \mathrm{C}$.

$t$ In terms of content of endotoxin before incubation. $\ddagger$ Aliquot tested: 0.14 to $1.0 \mathrm{ml}$ per animal. 


\section{Inhibition by divalent cation}

In studies previously reported from this laboratory it was shown that calcium, barium, magnesium and manganese divalent cations inhibit the enzymatic degradation of endotoxin by plasma (22). With the pyrogen assay, the previous observations on the inhibitory effect of divalent cation were extended to still other cations. The experiments were carried out with a limiting concentration of resin-treated plasma so that even relatively small inhibitory effects would be detected. To prevent clotting, resin-treated plasma was heparinized $(0.2 \mathrm{mg}$ per $\mathrm{ml})$ prior to the addition of divalent cation, all of which were tested in a concentration of $1 \times 10^{-3} \mathrm{M}$. In control tests without plasma these cations, incubated with endotoxin alone for 30 minutes, produced no alteration in pyrogenic potency. For calculation of the relative inhibitory effects of these cations, the pyrogenic response to an unincubated plasmaendotoxin mixture was assigned the value of 100 per cent while the response to the incubated mixture was designated zero. All six cations inhibited the degradation of endotoxin by plasma; however, calcium was more inhibitory than the others (Table V). Differences in the test conditions presumably account for the differences in the effect of cuprous ion from that obtained in some earlier experiments (22).

\section{Comparison of plasma from different species}

Although citrated plasma from rabbit and man were about equally effective in degrading endotoxin, wide variations were found in this ability of plasma from other species. Similar reaction mixtures were prepared with pooled citrated plasma

TABLE V

Inhibition by divalent cation *

\begin{tabular}{cc}
\hline Divalent cation & Inhibition $\dagger$ \\
\hline $1 \times 10^{-3} M$ & $\%$ \\
$\mathrm{Ca}$ & 68 \\
$\mathrm{Cu}$ & 48 \\
$\mathrm{Hg}$ & 42 \\
$\mathrm{Mg}$ & 41 \\
$\mathrm{Zn}$ & 39 \\
$\mathrm{Mn}$ & 30
\end{tabular}

* Reaction conditions : resin-treated human plasma $32 \%$,

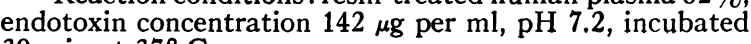
$30 \mathrm{~min}$ at $37^{\circ} \mathrm{C}$.

† Complete inhibition $=100 \%$.

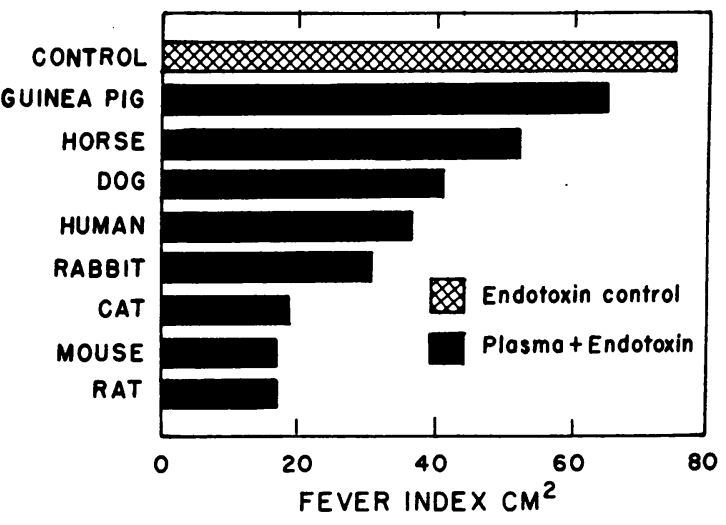

Fig. 7. THE CAPACITY OF PLASMA FROM DIFFERENT SPECIES to InACTIVATE ENDOTOXIN IN VITRO. Conditions of reaction: citrated plasma 36 per cent, concentration of endotoxin $142 \mu \mathrm{g}$ per $\mathrm{ml}, \mathrm{pH} 7.1$ to 7.4 , incubated 60 minutes at $37^{\circ} \mathrm{C}$. Aliquot tested: $0.14 \mathrm{ml}$ per animal.

from eight species. The concentration of plasma was limited to 36 per cent, while the concentration of endotoxin was in excess. After 1 hour of incubation the residual pyrogenicity was measured in assays of equal aliquots from each reaction mixture. In control tests, aliquots of each of the plasmas were found to be pyrogen-free (fever indices of $4 \mathrm{~cm}^{2}$ or less), except those of the cat and dog, which produced febrile responses of 9 and $10 \mathrm{~cm}^{2}$, respectively. Figure 7 illustrates the relative effectiveness of plasma from eight species to degrade endotoxin when reacted under the same conditions. Guinea pig plasma was weakest in this reaction; however, it was not devoid of enzymatic activity. Separate experiments, in which reaction mixtures were prepared at $\mathrm{pH} 9.5$ and the concentration of guinea pig plasma was increased to 72 per cent, demonstrated that the fever index could be reduced to $47 \mathrm{~cm}^{2}$ after 1 hour of incubation. Nevertheless, even under these favorable conditions, the degradation proceeded far more slowly than with plasma from other species.

\section{DISCUSSION}

It is now clear that serum normally possesses components which may either augment or reduce the pyrogenicity of endotoxin, depending upon the conditions of reaction. This investigation showed that reduction of pyrogenic potency is dependent upon $\mathrm{pH}$ and adequate concentration of plasma and of endotoxin, as well as upon the time and temperature of incubation. In addition, minute 
quantities of many divalent cations, especially calcium, nonspecifically inhibit the degradation of endotoxin by plasma. Rosen, Skarnes, Landy and Shear, working in this laboratory, demonstrated that differences in concentrations of calcium account for the fact that citrated or resin-treated plasma is more active in degrading endotoxin than is serum or heparinized plasma (22).

Investigators who demonstrated augmentation of the pyrogenic effects of endotoxin by serum generally employed reaction mixtures that contained low concentrations of endotoxin. Furthermore, augmentation was evident after incubation of serum with endotoxin at refrigeration temperatures, or even at $37^{\circ} \mathrm{C}$, provided the time was sufficiently short $(3,4,6,8)$. The data in this report show that these conditions of reaction are unfavorable for the degradation of endotoxin. Therefore, the augmenting effects of serum would be expected to overshadow the pyrogen-inactivating effects.

On the other hand, investigators who employed reaction mixtures which contained high concentrations of endotoxin, or mixtures that were incubated for prolonged periods at $37^{\circ} \mathrm{C}$, usually observed a reduction in the pyrogenic and other toxic properties of endotoxin $(8,10,14-18)$. In much of the earlier work, however, insufficient attention was given to the critical importance of the relative concentrations of the reactants. For example, the concentration of endotoxin was varied widely, primarily to conform to the range of measurement and the sensitivity of the particular assay used. Now that the enzymatic nature of the reaction is known, more definitive data can be obtained if reaction mixtures are prepared with primary consideration upon the concentrations rather than on the amount of endotoxin required for a particular assay procedure.

Although it is now evident that the inactivation of endotoxin by plasma is an enzyme-catalyzed reaction, it remains for future work to identify the reaction products. In the series of experiments described here, the progress of the reaction was followed by measuring residual substrate (endotoxin) concentration. Because the fever index was consistent over a wide range of dose-related measurements it was particularly useful for this purpose. Employment of this assay as a measure of residual endotoxin is based on the inference that the residual fever-producing substance in plasmaendotoxin reaction mixtures is unaltered endotoxin.

Grant and Whalen have suggested that so-called endogenous pyrogen, which is present in serum of febrile animals 2 hours after the injection of endotoxin, is exogenous endotoxin which has been altered by host plasma (4). This suggestion prompted experiments, some of which are described here, to determine whether the residual pyrogen of incubated plasma-endotoxin reaction mixtures had the pyrogenic properties of endogenous serum pyrogen. It was readily shown that animals tolerant to endotoxin were also tolerant to the residual pyrogen. In addition, daily injections of the residual pyrogen induced endotoxin tolerance. Perhaps the most distinctive quality of endogenous pyrogen is that it is equally pyrogenic for normal and endotoxin-tolerant animals. Therefore, it would appear that the residual pyrogen of incubated plasma endotoxin reaction mixtures is not endogenous pyrogen.

The differences in the enzymatic activity of citrated plasma collected from different species remain unexplained. It was suspected that these differences might be more apparent than real and that they could be due to variations in levels of the pyrogen-augmenting factor. An exploratory experiment showed that plasma from rat (most active) and guinea pig (least active) were equally capable of augmenting the pyrogenic effects of endotoxin. However, further study is needed before this possibility can be eliminated. All plasma samples were citrated to the same extent, but there were necessary variables in the techniques used to collect the blood. For example, some of the animals were anesthetized and some were not. Also, some species were exsanguinated, whereas relatively small samples of blood were collected from others. However, in this respect it is noteworthy that identical techniques were used in collecting blood from guinea pig (least active) and rat (most active).

Although the susceptibility of different species to endotoxin varies widely, all possess, to a greater or lesser degree, the capacity to detoxify these noxious agents. The enzymatic properties of plasma described here might conceivably be implicated in the defense of the host against endotoxin. However, it is noteworthy that lethal doses of 
tissue-destructive agents such as ionizing irradiation (24) and nitrogen mustard markedly reduce host resistance to infection, but leave the level of endotoxin-degrading enzymes apparently unaltered (25). Furthermore, it was shown that the plasma level of such enzymes in different species bore no discernible relationship to their susceptibility to endotoxin. Indeed, they may simply represent tissue enzymes which have been shed into the circulation, either for excretion or transport to other cells $(26,27)$; nevertheless, the present findings do not exclude the possible participation of this plasma enzyme in host resistance.

It has been repeatedly shown that cells of the reticuloendothelial system clear endotoxin from the circulation and that damage to these cells renders the host more susceptible to the toxic effects of endotoxin (28). Recent experiments in this laboratory have shown that soluble endotoxindegrading enzymes are extractable from many tissues, including kidney, liver and leukocytes $(1,2)$. Consequently, it is possible that the enzyme in plasma originates from a variety of tissues, including the reticuloendothelial system; the presence of such enzymes in phagocytic cells may prove to be of special significance in host resistance to the noxious effects of endotoxin.

\section{SUMMARY}

The inactivation of endotoxin by blood plasma was found to have the characteristics of an enzyme-catalyzed reaction. The reaction was dependent upon the concentration of reactants and the $\mathrm{pH}$ of the reaction mixture, as well as on the time and temperature of incubation. Products of the enzymatic degradation of endotoxin by plasma were nonpyrogenic.

\section{REFERENCES}

1. Waravdekar, V. S., Trapani, R-J., Landy, M., and Shear, M. J. Inactivation of endotoxic polysaccharide by tissue homogenates. Fed. Proc. 1960, 19, 245.

2. Keene, W. R., and Landy, M. Unpublished observations.

3. LeQuire, V. S. The augmentation of the thermogenic effects of pyrogens by homologous plasma in rabbits. J. infect. Dis. 1951, 88, 194.

4. Grant, R., and Whalen, W. J. Latency of pyrogen fever. Appearance of a fast-acting pyrogen in the blood of febrile animals and in plasma incubated with bacterial pyrogen. Amer. J. Physiol. 1953, $173,47$.

5. Grant, R. Refractoriness to pyrogens. Effects of incubation of pyrogen with plasma from normal and refractory donors on the responses of refractory recipients. Amer. J. Physiol. 1953, 173, 246.

6. Farr, R. S., Clark, S. L., Jr., Proffitt, J. E., and Campbell, D. H. Some humoral aspects of the development of tolerance to bacterial pyrogens in rabbits. Amer. J. Physiol. 1954, 177, 269.

7. Cluff, L. E. A study of the effect of serum on the immunological reaction of a bacterial endotoxin. J. exp. Med. 1956, 103, 439.

8. Cluff, L. E., and Bennett, I. L., Jr. Factors influencing the alteration of the pyrogenic action of endotoxin by serum. Bull. Johns Hopk. Hosp. 1957, 101, 281.

9. Hegemann, F. Zur bedeutung des Blutserums fur die Entstehung und das Unwirksamwerden bakterieller Reizstoffe beim Menschen. Die neutralisierende Wirkung des menschlichen Serums auf das Endotoxin von Colibakterien. Z. Immun.Forsch. 1954, 111, 213.

10. Hegemann, F. Studien über die Natur des fieberstoffneutralisierenden Faktors im normalen menschlichen Blut. I. Ueber die Neutralisierung bakterieller Polysaccharide und zur Frage der Immunkörperwirkung. Z. Immun.-Forsch. 1955, 112, 340 .

11. Hegemann, F. Studien über die Natur des fieberstoffneutralisierenden Faktors im normalen menschlichen Blut. Die Temperaturempfindlichkeit des neutralisierenden Faktors und die seiner Wirksamkeit. Z. Immun.-Forsch. 1956, 113, 201.

12. Hegemann, F., and Lessmann, $H$. Studien über die Natur des fieberstoffneutralisierenden Faktors im normalen menschlichen Blut. V. Ueber das Vorkommen des endotoxinneutralisierenden Serumfakotors bei verschiedenen Tierarten. Z. Immun.Forsch. 1958, 115, 391.

13. Rall, D. P., Gaskins, J. R., and Kelly, M. G. Reduction of febrile response to bacterial polysaccharide following incubation with serum. Amer. J. Physiol. 1957, 188, 559.

14. Kelly, M. G., Smith, N. H., and Rall, D. P. Effect of incubation with rabbit serum on toxicity and tumor-necrotizing action of polysaccharide from S. marcescens. Amer. J. Physiol. 1957, 188, 563.

15. Ho, M., and Kass, E. H. Protective effect of components of normal blood against the lethal action of endotoxin. J. Lab. clin. Med. 1958, 51, 297.

16. Landy, M., Skarnes, R. C., Rosen, F. S., Trapani, R-J., and Shear, M. J. Inactivation of biologically active ("endotoxic") polysaccharides by fresh human serum. Proc. Soc. exp. Biol. (N. Y.) 1957, 96, 744.

17. Lüderitz, O., Hammer, D., Goebel, F., Sievers, K., and Westphal, $O$. Die Inaktivierung der endo- 
toxischen Wirksamkeit bakterieller Lipopolysaccharide in Serum, Plasma und Vollblut vom Pferd. Z. Naturforsch. 1958, 13, 566.

18. Skarnes, R. C., Rosen, F. S., Shear, M. J., and Landy, M. Inactivation of endotoxin by a humoral component. II. Interaction of endotoxin with serum and plasma. J. exp. Med. 1958, 108, 685.

19. Landy, M., Trapani, R-J., and Shear, M. J. Inactivation of endotoxin by a humoral component. IV. Alteration in the immunological properties of typhoid endotoxin. J. exp. Med. 1959, 110, 731.

20. Stauch, J. E., and Johnson, A. G. The alteration of bacterial endotoxins by human and rabbit serum. J. Immunol. 1959, 82, 252.

21. Keene, W. R., Silberman, H. R., and Landy, M. Observations on the pyrogenic response and its application to the bioassay of endotoxin. J. clin. Invest. 1961, 40, 295.

22. Rosen, F. S., Skarnes, R. C., Landy, M., and Shear, M. J. Inactivation of endotoxin by a humoral component. III. Role of divalent cation and a dialyzable component. J. exp. Med. 1958, 108, 701.
23. Shear, M. J., Perrault, A., and Adams, J. R., Jr. Chemical treatment of tumors. IV. Method employed in determining the potency of hemorrhageproducing bacterial preparations. J. nat. Cancer Inst. 1943, 4, 99.

24. Rosen, F. R., and Landy, M. Inactivation of endotoxin by a humoral component. V. EDC activity during Gramnegative infection and shock. Z. Immun.-Forsch. 1959, 118, 262.

25. Keene, W. R., and Landy, M. Unpublished observations.

26. Surgenor, D. M., Hunter, M. J., and Brown, R. K. The nature and properties of the enzymes of normal human plasma in Blood Cells and Plasma Proteins, Their State and Nature, J. L. Tullis, Ed. New York, Academic Press, 1953, p. 315.

27. Zierler, K. L. Muscle membrane as a dynamic structure and its permeability to aldolase. Ann. N. Y. Acad. Sci. 1958, 75, 227.

28. Beeson, P. B. Tolerance to bacterial pyrogens. II. Role of the reticulo-endothelial system. J. exp. Med. 1947, 86, 39. 